\title{
Cultural Awareness in Chinese-English Translation
}

\author{
Jinhong Yu \\ Foreign Languages Department, University of Shanghai for Science and Technology, Shanghai, China
}

\begin{abstract}
There are very important cultural factors in translation practice, especially in Chinese-English translation. The learners' cultural awareness is of utmost importance in Chinese-English translation. Translation refers to the interaction between two languages, and also the communication between two cultures. However, owing to the differences between Chinese and western cultures, it is not easy for translators to convey the exact meaning of the languages without good understanding of the cultures. So, it is both important and necessary to have cultural awareness while doing Chinese-English translation.
\end{abstract}

Index Terms - cultural factors, cultural awareness, translation, consideration

\section{INTRODUCTION}

Culture refers to the cumulative deposit of knowledge, experience, beliefs, values, attitudes, meanings, hierarchies, religion, notions of time, roles, spatial relations, concepts of the universe, and material objects and possessions acquired by a group of people in the course of generations through individual and group striving (Dai weidong, He zhaoxiong, 2002). Culture has many different meanings. Culture is a powerful human tool for survival and communication.

Cultural awareness includes awareness of our own culture and other cultures. The awareness is gained from experiencing the culture, and according to Tomlinson (2001), it is "a gradually developing inner sense of the equality of the cultures, an increased understanding of one's own and other people's cultures, and a positive interest in how cultures both connect and differ. Such awareness can broaden the mind, increase tolerance and facilitate international communications. "(cited in Tomlinson \& Masuhara, 2004, p. 3).

Increased cultural awareness can give us increased credibility and expertise. It can also help us to achieve cultural empathy and sensitivity (Tomlinson \& Masuhara, 2004). Doing translation is not simply to translate the meaning of a passage from one language into another. It is really a complicated task that requires very good understanding of the cultures of both the source language and the target language. Eugene A. Nida (2001) states, "the role of language within a culture and the influence of the culture on the meanings of words and idioms are so pervasive that can scarcely any text be adequately understood without careful consideration of its cultural background." (Nida, Eugene A. 2001, P13) Richard E. Porter and Larry A. Samovar also explain: "Intercultural communication occurs whenever a message producer is a member of one culture and a message receiver is a member of another." (Porter \& Samovar, 1998:15) Therefore, translation, as a cross-lingual communication, is both the transformation from one language to another and from one culture to another. Language is a part of culture, and when people do translation from one language into another, they should pay attention to the necessary knowledge of the two cultures involved.

\section{Culture, Language and Translation}

Culture and Language are two indispensable conceptions in the discussion of Translation. Language is the human capacity for acquiring and using complex systems of communication. Language is also a social phenomenon, and people from different cultures use different languages to communicate in daily life. Translation works make it easier for people from different cultures to understand each other more and better.

Culture, in a broad sense, is a total way of life of a people, including the patterns of people's belief, customs, techniques and language that characterize the life of the people. Language is a very important medium to express cultural notes. People read and write and communicate with each other in languages on the basis of cultural understanding. In this sense, culture and language intrinsically depend on each other in communications.

Very importantly, culture conditions the forms of languages. No language can be separated from its culture.

In translation practice, translators should be clear about the relation between culture and language, and the importance of the cultural implications in communication.

See the following example:

1) 周瑞家的听了笑着说道: “阿弥陀佛, 真真坑死人的事儿, 等十年都未必这样巧的呢!”(Cao \& Gao, 2000)

This is a part from one of the master pieces of Chinese classical novels — 《红楼梦》 (A Dream of Red mansions by Cao xueqin). It has two different English translation versions which are both widely accepted in China: one was done by famous Chinese translator Yang xianyi (杨宪益) and his wife, Gladys Yang; the other was translated by British sinologist David Hawkes. Let's compare their translations of the sentence above: 
A. "Gracious Buddha!" Mrs Zhou chuckled, "How terribly chancy! You might wait for ten years without such a run of luck!" (Yang xianyi and Gladys Yang, 2012)

B. "God bless my soul!" ZhouRui's wife exclaimed, "You would certainly need some patience! Why, you might wait ten years before getting all these things at the proper times!" (David Hawkes, 1977)

These two examples clearly show that the two translators have very different cultural awareness when doing the translation. As a traditional Chinese person, Yang had a conventional understanding of the religious note mentioned in this sentence: 阿弥陀佛. In china, Buddhism is the dominating religion. So Yang translated this as: "Gracious Buddha"; while the British translator was more interested in God. This is quite accepted in different groups of readers. The translation versions are different because of the translators' different cultural awareness. But Yangs' translation makes the readers (especially the foreign readers) know more about the Chinese culture.

\section{Cultural Factors And Cultural Awareness}

There are important cultural factors in both language teaching and translation practice. Each language has its own genius, and to communicate effectively one must respect the genius of each language; To preserve the content of the message the form must be changed (Nida and Taber 1969), and translation just means to convey the genius of languages in different forms. According to Nida, a culture of a society is reflected in certain aspects of its language, but a language does not, however, reflect the culture automatically (Nida, 2002). Translators should consciously avoid close reproduction of the syntactical structures of the source language, and aim at a natural rendering in the receptor language. In translation practice, translators should also take the important cultural factors into account to get the better version of translation. In his book "Linguistics and Ethnology in Translation-Problems", Nida listed the following cultural factors that are closely related to the translation practice: the ecological culture, the material culture, the social culture, the religious culture, and the linguistic culture. (Nida: 1964) As we are considering the Chinese-English translation practice, we will see some examples and try to interpret the importance of cultural awareness in Chinese-English translation.

1. The ecological culture

The ecological-culture refers to the system established by a nationality in the process of adapting, utilizing and transforming the environment. Generally it covers the religious beliefs, modes of production, lifestyles, social organization and customs of this nationality when it interacts with the environment. The ecological culture can adjust the relationship between man and nature according to the requirement of ecological rules, actively reflect the features of eco-system working, and lead the eco-system towards harmony, stability and prosperity. In Chinese-English translation practice, we find it very significant to have eco-cultural awareness to make a better version in translation.

See the following examples:

(2) .....古人所言的梧桐一叶而天下知秋的遥想, 大约也就在这些深沉的地方。(Yu Dafu, 2005)

In this sentence, the expression 梧桐 has very rich cultural contents in Chinese culture. Firstly it means nobility. That's why we Chinese say “梧桐引来金风凰”。Sometimes it means sadness and isolation, especially in ancient poems and writings. In English, it has a widely accepted translation: Chinese Parasol tree. But in this sentence, if it is translated in this way, it delivers little cultural contents. So we have the following translation:

The same depth of implication is found in the ancient saying that a single fallen leaf from the wutong tree is more than enough to inform the world of autumn's presence. (Zhang Peiji, 2007)

Obviously the Chinese pinyin "wutong" in professor Zhang Peiji's translation gives the readers much more information about Chinese culture. Here is another example:

(3) 真愿成为诗人, 把一切好听好看的字都浸在自己的心血里, 像杜鹃似啼出北平的俊伟。(Lao She, 2012)

Just as the above sentence, the expression “杜鹃” in the sentence is considered as one of the symbols of Chinese culture. In ancient China, the cry of the bird (杜鹃) was considered sharp and desperate, reminding people of their sad memories. In Chinese, we use “杜鹃啼血” (cuckoo lament) to express homesickness, so professor Zhang Peiji translated it in the following way:

If only I were a poet so that, with all the sweet and beautiful words at my command, I could sing of the grandeur of Peiping in as longing a note as that of a cuckoo! (Zhang Peiji, 2007)

In nature, everything (an animal or a plant) has its own meaning and when they live harmoniously together, they all have implications cultural contents. In translation, their implications and cultural contents mean a lot to the readers.

1. 2. The material culture

The material culture includes people's eating habits and their customs and understanding in everyday life. In translation practice, we say many examples which really need careful consideration in culture.

(4) …离开了咸菜缸却又跳进了萝卜窝. (Jiang Zilong, 2008 )

In this sentence, 咸菜缸 and 萝卜窝 are culture-specific expressions in Chinese, both of which mean containers to make salted vegetables; and the intended meaning of the whole message 离开了咸菜缸又跳进了萝卜窝 has nothing to do with its literal interpretation. Here it has the implication of "from bad to worse". So an English image should be substituted for that typical Chinese image, i.e. jump out of the frying pan into the fire. According to Nida (1982), to preserve the content of the message, the form must be changed, and we can see that when it is translated in this way, 
even the foreign readers will easily get its meaning. (Nida 1982)

(5) 巧媳妇做不出无米的粥来。(Cao \& Gao, A 2000)

See the first translation version by David Hawkes:

Even the cleverest housewife can't make bread without flour! (David Hawkes, 1977)

David Hawkes was the British Sinologist and great translator. His most important translated work was The Story of the Stone, which was also known as The Dream of the Red Chamber, and his translation version was widely accepted in foreign world. Because of the cultural difference, there are different interpretations in certain parts of his translation.

Obviously the above translated text violates the principle of cultural equivalence. From ancient time up to now, rice prevails as the staple food of most Chinese in daily life, though bread is less uncommon in China. Therefore, the adaptation of rice to bread does not conform to the Chinese cultural background. His translation is acceptable, but not the best. Another translation version with more cultural sense by Yang xianyi would be easier to understand:

Even the cleverest housewife can't cook a meal without rice. (Yang xianyi, 2012)

3. The social culture

In a broad sense, the social culture refers to the social values, the interrelationships among people, political and economic relations, conventions and customs of a certain society. The social culture plays a very important role in Chinese-English translation. Let's see the following examples:

(6) 必须始终不渝地坚持两手抓, 两手都要硬的方针, 加强精神文明建设。(Deng Xiaoping, 2004)

In this sentence, “两手抓, 两手都要硬” and “精神文明建设” are typical expressions in current Chinese politics. If translated literally as "grasp with two hands, and two hands should be equally tough", and"spiritual civilization construction", they will become very difficult to understand for foreign readers. In translating expressions peculiar to Chinese politics, especially metaphors like these, the translators have to pay enough respect to the social cultural and political habits of foreign readers. So “两手抓, 两手都要硬” can be translated as "to attach equal importance to something” and “精神文明建设” “the development of socialist culture and ideology”. We translate the sentence as:

We must unswervingly give equal importance to economic development on one hand and to the development of socialist culture and ideology on the other hand. (Deng Xiaoping, 2004)

（7）嫁鸡随鸡, 嫁狗随狗。(Chen Hongwei, 2003 )

A: If a woman marries a chicken, she should act like a chicken; if she marries a dog, she should act like a dog. (Fox Butterfield Alive in the Bitter Sea p.162)

People will feel puzzled by the above version by Fox Butterfield, an American journalist, because he did not understand the real meaning of the proverb, and failed to consider its cultural implication in translation. Its figurative meaning is that once a girl has attached herself to a man, she must be faithful to him forever regardless of all circumstances - to advise a girl to be contented with the man she has married. So the following version sounds much better:

B: Marry a cock and follow a cock, marry a dog and follow a dog---- throw in one's lot with one's husband. (Chen Hongwei, 2003)

In this kind of translation, a note is so helpful for the foreign readers to interpret the cultural implications in the sentence.

(8) 阿 $\mathrm{Q}$ 本来也是正人, 我们虽然不知道他曾蒙什么明师指授过, 但它对于 “男女之大防”却也历来非常严。( $\mathrm{Lu}$ Xun, 2012)

Chinese people were influenced deeply by the puritanical ethics of traditional Confucian morality in history, and any contact between an unrelated man and woman was considered immoral. A popular proverb decreed that "a man and woman, unless related, should not touch hands when giving or receiving things” (男女授受不亲). Chinese people can easily associate “男女之大防” with “男女授受不亲” and know their meanings. But it will be easier for foreign readers to understand the cultural contents with such a note:

Now our Ah Q started out as an upright man too. Though we don't know if this was because he had been shown the way by some enlightened teacher, we do know that he rigorously observed the great barrier that should be 'twixt the he and she - In China, a man and woman, unless related, should not touch hands when giving or receiving things. (William A. Lyell, 2012)

Let's see another example from the same book:

(9) “这断子绝孙的阿 Q!” 远远地听到小尼姑的带哭的声音。(Lu Xun, 2012)

In China, to say someone dies sonless is a curse intolerable to Chinese ears. Here a note is very necessary for the foreign readers because in the west, if someone died sonless, he would not be considered undutiful to ancestors. This is greatly different from what Chinese value, as we traditionally see that "no offspring is the worst one of the three ways unfilial to our ancestors" (不孝有三，无后为大):

“Ah Q, may you die sonless!" Sounded the little nun's voice tearfully in the distance —a curse intolerable to hear in China (William A. Lyell, 2012).

From the above examples we can see that understanding of the social culture means a lot in Chinese-English translation.

4. The religious Culture 
Religion is a system of beliefs concerning the cause, nature, and purpose of the universe, and people show their religious ideas in life through languages and cultures. But "religion and culture" is a broad subject. In translation, we need to understand the close relationship between religion and culture to do a good job.

Let's see the following example:

(10)他父亲心境不好, 准责备儿子从前不用功急时抱佛脚, 也许还有一堆“亡羊补牢, 教学相长”的教训。(Qian Zhongshu,1991)

Considering Chinese people's religious awareness, the expression “急时抱佛脚” really has religious implications. It means in religion that a person should always be pious. It will be too late if he only prays for help when in trouble. In life, people now use the expression widely to mean that it is too late for people to do what they should do before. But the literary translation of the expression “抱佛脚”will make it hard to understand for the foreigners, as they have different religions, and the literary meaning has almost nothing to do with the real meaning of the sentence.

So, the sentence can be translated as:

If his father were in bad mood, he would undoubtedly rebuke him for not having studied harder before and only cramming everything in at the last minute. There might even be admonitions about "repairing the fold after the sheep are lost," or "one learns as one teaches".

(11) “谋事在人, 成事在天。”咱们谋到了, 靠菩萨的保佑, 有些机会, 也未可知。(Cao \& Gao, 2000)

Just as we mentioned in the above paragraphs, Chinese people have different religious belief compared with the western people. So if “谋事在人，成事在天” is translated as “Man proposes, God disposes”, the western people will lose the chance to understand the religious information of Chinese people. Translator Yang xianyi substituted God with heaven to help them understand both the semantic and cultural messages of the sentence:

Man proposes; heaven disposes. Work out a plan, trust to Buddha and something may come of it for all you know. (Yang xianyi and Gladys Yang, 2012)

5.The linguistic culture

Language is not only an important part of culture, but also a carrier. Languages have different features, and when people use their own languages to express their ideas, cultural features are becoming clear. In translation practice, translators have to consider carefully the linguistic features and the habits of both the languages and then it is possible to make a better version in translation.

(12) 老子煎謷了小半辈子, 还让老婆跟着受委屈. (Chen Hongwei, 2003)

Many Chinese are used to expressing themselves in such a way; here in the sentence, 小半辈子 actually means the time from the birth to the time that the words were said. So some translators would do it in this way:

(A)I have endured hardships for nearly half of my life, and my wife has suffered all along with me.

When the foreign readers read this, they may think that he has not suffered for some time in his life, as they have different interpretation of the phrase "nearly half of my life", according to their way of expression. So, the expression" for nearly half of my life" should be changed into" for all my life", just as mentioned in the above, the expression“小半辈子”, actually means the time from the birth to the time that the words were said. So:

(B) I have endured hardships for all my life, and my wife has suffered all along with me.

(13) 感情深, 一口闷; 感情浅, 舔一硚 (Wang wuxing, 2004)。

This kind of structure is very popular in Chinese, and Chinese people have no difficulty interpreting its implications. When translating it into English, literary translation will not work. So we see the following version:

If we are great friends, we should drink it all in one mouthful. If we are on speaking (nodding) terms, we can just sip it. (Wang Wuxing, 2004)

The translator added if to make his translation conform to English syntax. In this way he also made the implied meanings clear to the target language readers.

\section{CONCLUSION}

The cultural factors are so important that in Chinese-English translation, if they are overlooked, the readers will fail to interpret the original meanings of the Chinese works. Thus the English translation version would mean little to them. The translators should pay more attention to both the Chinese culture and the English culture, and lay enough emphasis on the cultural factors, and improve their cultural awareness in translation practice. With good cultural awareness the translators will successfully transfer the original meaning of the source language to the target language with its rich cultural contents.

\section{REFERENCES}

[1] CaoXueqin, Gaoe. (2000). A Dream of Red Mansions, The People’s Literature Publishing House, Beijing.

[2] Chen Hongwei. (2003). Basic English Translation, Shanghai Foreign Language Education Press, Shanghai.

[3] Dai Weidong, He Zhaoxiong. (2002: p 127). A New Concise Course on Linguistics For Students Of English, Shanghai Foreign Language Education Press, Shanghai.

[4] David Hawks. (1977). The Story of the Stone, Penguin Classics, London. 
[5] Deng Xiaoping. (2004). Selected Works of Deng Xiaoping, Renmin Publishing House, Beijing.

[6] Jia Dejiang. (2002). Contrastive studies of English and Chinese and Translation, National University of Defense Technology Publishing House, Beijing.

[7] Jiang Zilong. (2008). Three-dimensional People, People's Fine Arts Publishing House, Beijing.

[8] Lan Ping. (2010). A Cultural-Oriented Course on English-Chinese Translation, China Renmin University Press, Beijing.

[9] Lao She. (2012). Fond Memories of Peiping, The People's Literature Publishing House, Beijing.

[10] Lu Xun. (2012). Ah Q-The Real Story, Hunan Education Publishing House, Changsha.

[11] Nida, Eugene A. (2002). Contexts in Translating, John Benjamins Publishing Company, Amterdam).

[12] Nida, Eugene A. (2001). Language and Culture: Context in Translation, Shanghai Foreign Language Education Press, Shanghai.

[13] Nida, Eugene A and Charles. R Taber. (1969). The Theory and Practice of Translation. Leiden: Brill.

[14] Nida, Eugene A. (1964). Linguistics and Ethnology in Translation-Problems [A]. Language in Culture and Society: A Reader in Linguistics and Anthropology. Ed. Dell Hymes. New York: Harper \& Row Publishers.

[15] Nida Eugene A. (1982). Translating Meaning, California, English Language Institute.

[16] Qian Zhongshu. (1991). Fortress Besieged, The People's Literature Publishing House, Beijing.

[17] Tomlinson B. \& Musuhara, H. (2004). Developing cultural awareness, MET, 13(1), 1-7

[18] Tomlinson, B. (2003). Developing Materials in Language Teaching. London: Continuum Press.

[19] Tomlinson, B. (2005). Testing to learn: a personal view of language testing. ELT Journal, Oxford University Press.

[20] Samovar L. A., Porter R. E. \& Stefani L. A. (1998). Communication between Cultures, Third Edition, Belmont et al.: Wadsworth Publishing Company.

[21] Yang xianyi and Gladys Yang. (2012). A Dream of Red Mansions, Foreign Language Press, Beijing.

[22] Yu Dafu. (2005). Autumn in Peiping, Jinghua publishing House, Beijing.

[23] William A. Lyell. (2012). Ah Q-The Real Story, Hunan Education Publishing House, Changsha.

[24] Zhang Peiji. (2007). Selected Modern Chinese Essays, Shanghai Foreign Language Education Press, Shanghai.

Jinhong Yu is an associate professor in University of Shanghai for Science and Technology, Shanghai, China. She received her M.A. degree in Foreign Languages Department of Shanghai Normal University in 1999. She has been teaching English and culture for many years and she is greatly interested in translation and culture. Her research interests are foreign language teaching and translation. 